\title{
Development and validation of RP-HPLC method for simultaneous determination of diclofenac sodium and tizanidine hydrochloride in bulk and tablet formulation
}

\begin{abstract}
A reverse phase high performance liquid chromatographic method (RP-HPLC) has been developed for the simultaneous estimation of Diclofenac sodium (DICS), and Tizanidine Hydrochloride (TIZH) in the pharmaceutical formulation. The chromatographic column used was a reverse phase $4.6 \mu 250 \mathrm{~mm}$ Hypersil $\mathrm{C}_{18}$ HPLC column with $5 \mu \mathrm{m}$ (particles) packing. The mobile phase was ACN: Phosphate buffer $\mathrm{pH} 7.0(50: 50 \mathrm{v} / \mathrm{v})$ delivered at a flow rate of $1.0 \mathrm{~mL} / \mathrm{min}$. The injection volume was $25 \mu \mathrm{L}$. Elute was analyzed by a UV detector set at $220 \mathrm{~nm}$. Linearity was obtained inthe concentration range of $2-10 \mu \mathrm{g} / \mathrm{ml}$ for DICS, $2.5-12.5 \mu \mathrm{g} / \mathrm{ml}$ Tizanidine hydrochloride. The method was statistically validated and RSD was found to be less than $2 \%$ indicating high degree of accuracy and precision of the proposed HPLC method. Due to its simplicity, rapidness, high precision and accuracy, the proposed RP-HPLC method may be used for determining Diclofenac Sodium and Tizanidine Hydrochloride in bulk drug samples.
\end{abstract}

Keywords: diclofenac sodium, tizanidine hydrochloride, high performance liquid chromatography, syringe, ultrasonicator
Volume 7 Issue 2 - 2018

\author{
Sonali D Labhade,' Sanjay R Chaudhari,' Ravi \\ B Saudagar ${ }^{2}$ \\ 'SJVPM's RMD Institute of Pharmaceutical Education and \\ Research, India \\ ${ }^{2}$ KCT's, R G Sapkal College of Pharmacy, India
}

Correspondence: Sonali D Labhade, SJVPM's RMD Institute of Pharmaceutical Education and Research, Pune, India, Email sonalilabhade@yahoo.com

Received: January II, 2018 | Published: April 27, 2018

\section{Introduction}

Chromatography is the technique in which the components in a mixture of sample separated by passing through stationary phase with aid of mobile phase. The components which have more affinity with mobile phase elute faster than others. HPLC is the fastest growing analytical technique for analysis of drugs. Its simplicity, high specificity and wide range of sensitivity make it ideal for the analysis of many drugs in various dosage forms and biological fluids. The HPLC is the vital tool in the field of analysis of various pharmaceutical dosage forms, since this method is specific, robust, linear, precise and accurate and the limit of detection is low. The method development is an integral part of the method validation. Establishing documented evidence, provides that a specific activity will consistently produce a desired result or product meeting its predetermined specifications and quality characteristics of the samples. ${ }^{1-14}$

The validation parameters are Specificity, linearity, Accuracy, LOD, LOQ, Precision, Range, Robustness, System suitability Diclofenac sodium is chemically, 2-[(2-aminoethoxy)methyl]-4-(2chlorophenyl)-3- ethoxycarbonyl-5-methoxycarbonyl-6-methyl-1, 4-dihydropyridine benzenesulfonate.with moleular formual as $\mathrm{C}_{20} \mathrm{H}_{25} \mathrm{ClN}_{2} \mathrm{O}_{5} \cdot \mathrm{C}_{6} \mathrm{H}_{6} \mathrm{O}_{3} \mathrm{~S}$ (567.5). It is used as Anti-hypertensive (calcium channel blocker). It Slightly soluble in distilled water and sparingly soluble in ethanol. Tizanidine hydrochloride2 chemically, 5-chloro-4-(2-imidazolin-2-ylamino)-2,1,3-benzothiadiazole hydrochloride, is a short acting drug for management of spasticity. It is a 2-adrenergic agonist and centrally acting skeletal muscle relaxant. It has been found to be useful in relieving spasms. Literature survey reveals that various spectrophotometric3,4 and HPLC5-12 methods were reported for the individual determination of rofecoxib and tizanidine hydrochloride in pharmaceutical dosage forms. No method has been developed for the estimation of these drugs simultaneously. The present work describes a simple, precise and accurate HPLC method for the simultaneous estimation of rofecoxib and tizanidine hydrochloride in tablet dosage form.

\section{Instruments}

UV-Visible Spectrophotometer, HPLC, Ultra sonicator, $\mathrm{pH}$ meter, Electronic balance, Syringe, HPLC Column

Chemicals:

Diclofenac Sodium and Tizanidne Hydrochloride was obtained from Lupin Research Park, Pune. Methanol HPLC grade, ACN HPLC grade, Water HPLC grade was obtained from Merck India Ltd, Mumbai.

\section{Selection of mobile phase ${ }^{15}$}

The criteria employed for selection of particular solvent system for the analysis was cost, time required for analysis, sensitivity of the assay and solvent noise for the analysis of DICS and TIZH from tablet formulation. Literature review does not reveal any specific mobile phase for simultaneous estimation of DICS and TIZH.

Initially, various ratios of acetonitrile (ACN): water (HPLC grade) $25 \mathrm{mM}$ phosphate buffer $\mathrm{pH} 7$ were tried to develop a sensitive and accurate method like;

a. ACN: Water $(70: 30 \mathrm{v} / \mathrm{v})$

b. ACN: Water $(50: 50 \mathrm{v} / \mathrm{v})$ 
Then, phosphate buffer $\mathrm{pH} 7$ was used instead of water.

a. ACN: $25 \mathrm{mM}$ phosphate buffer $\mathrm{pH} 7(70: 30 \mathrm{v} / \mathrm{v})$

b. ACN: $25 \mathrm{mM}$ phosphate buffer $\mathrm{pH} 7(50: 50 \mathrm{v} / \mathrm{v})$

Preparation of standard stock solutions and selection of analytical wavelength ${ }^{15}$

Standard stock solutions $(100 \mu \mathrm{g} / \mathrm{mL})$ of DICS and TIZH were prepared separately. Dissolve $10 \mathrm{mg}$ of drug in $100 \mathrm{~mL}$ of volumetric flask with $50 \mathrm{~mL}$ of acetonitrile: water (HPLC grade) $(1: 1 \mathrm{v} / \mathrm{v})$ with shaking and then volume was made up to the mark with same solution.

By appropriate dilution of the standard stock solution with mobile phase, various concentrations of DICS and TIZH were prepared separately. Their spectra were obtained using the double beam UV visible spectrophotometer.

\section{Preparation of standard calibration curves of DICS and TIZH by HPLC method ${ }^{15}$}

\section{Chromatographic conditions}

The chromatographic column used was a reverse phase $4.6 \times 250 \mathrm{~mm}$ Hypersil $\mathrm{C}_{18}$ HPLC column with $5 \mu \mathrm{m}$ (particles) packing. The column and the HPLC system were kept at ambient conditions. The mobile phase was ACN: Phosphate buffer pH $7.0(50: 50 \mathrm{v} / \mathrm{v})$ delivered at a flow rate of $1.0 \mathrm{~mL} / \mathrm{min}$. The injection volume was $25 \mu \mathrm{L}$. Elute was analyzed by a UV detector set at $220 \mathrm{~nm}$.

For preparation of standard calibration curve, appropriate aliquots were pipette out from stock solutions into a series of $10 \mathrm{~mL}$ volumetric flasks. The volume was made upto the mark with mobile phase to obtain a set of solutions of DICS having concentration range 2-10 $\mu \mathrm{g} /$ $\mathrm{mL}$ each and $2.5-12.5 \mu \mathrm{g} / \mathrm{mL}$ for TIZH. Triplicate dilutions of each concentration of drug were prepared. From these triplicate solutions,

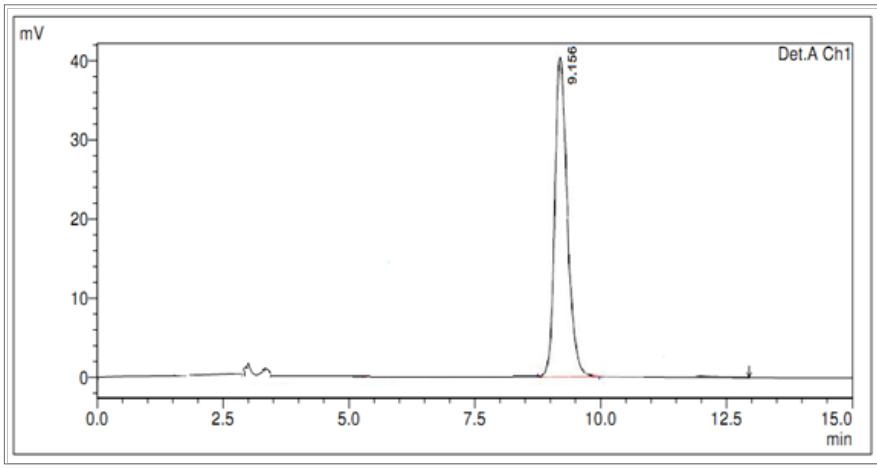

Figure I Chromatogram of pure DICS.

\section{Calibration curve of tizanidine hydrochloride by HPLC}

The chromatogram of pure drug at concentration $2 \mu \mathrm{g} / \mathrm{ml}$ is shown in Figure 3. The standard calibration curve and table for TIZH is shown in Figure 4 \& Table 2 respectively. A linear correlation was found between area under the curve and concentration in the ranges 2 to $12 \mu \mathrm{g} / \mathrm{ml}$ for tizanidine. The retention time was observed as $5.66 \mathrm{~min}$. The $\mathrm{r}^{2}$ of the calibration curve was found to be 0.996 .
$25 \mu$ injection of each concentration of drug was injected into the HPLC system. Evaluation of both drugs was performed with the UV detector set at $220 \mathrm{~nm}$. Peak area was recorded and working calibration curves were plotted separately with peak area Vs the respective concentration of DICS and TIZH.

\section{Chromatogram of pure drug}

\section{Calibration curve of diclofenac sodium by HPLC}

The chromatogram of pure drug at concentration $10 \mu \mathrm{g} / \mathrm{ml}$ is shown in Figure 1. The standard calibration curve and table for DICS is shown in Figure $2 \&$ Table 1 respectively. A linear correlation was found between area under the curve and concentration in the ranges 6 to $16 \mu \mathrm{g} / \mathrm{ml}$ for diclofenac sodium. The retention time was observed as $9.15 \mathrm{~min}$. The $\mathrm{r}^{2}$ of the calibration curve was found to be 0.998 .

Table I Concentration and area values for DICS

\begin{tabular}{lll}
\hline Sr. no. & Concentration $(\boldsymbol{\mu g} / \mathbf{m L})$ & AUC 220.0 at $\mathbf{~ m} *$ \\
\hline $\mathrm{I}$ & 0 & 0 \\
2 & 6 & 170493 \\
3 & 8 & 233270 \\
4 & 10 & 285990 \\
5 & 12 & 338344 \\
6 & 14 & 384983 \\
7 & 16 & 438985 \\
$\mathrm{R}^{2}$ & 0.998 & \\
Slope & 27403 & \\
Intercept & 6207 & \\
\hline
\end{tabular}

*Average of three determinants.

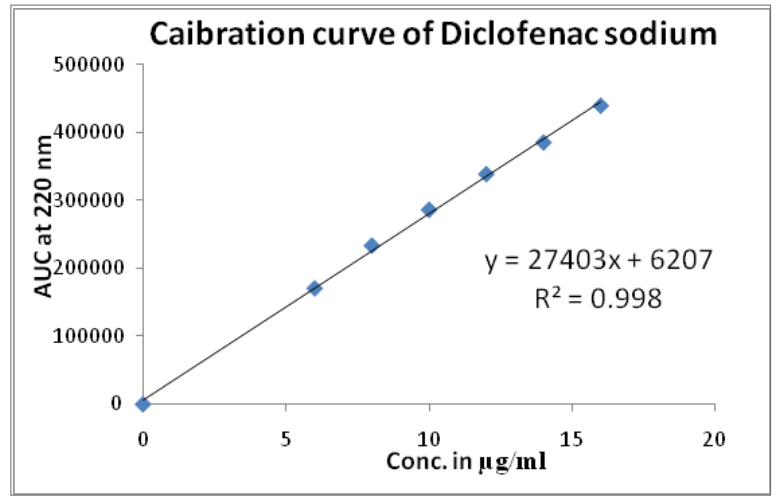

Figure 2 Calibration curve of DICS by HPLC.

\section{Method validation}

\section{Linearity}

The Calibration curves were found to be linear and in adherence to Beer's law over the concentration range of $6-16 \mu \mathrm{g} / \mathrm{ml}$ for DICS and $2-12 \mu \mathrm{g} / \mathrm{ml}$ for TIZH. The results of the linearity studies are given in Table 3. 
Table 2 Concentration and area values for $\mathrm{TIZH}$

\begin{tabular}{lll}
\hline Sr. No. & $\begin{array}{l}\text { Concentration } \\
(\mu \mathrm{g} / \mathrm{mL})\end{array}$ & AUC at 220.0nm* \\
\hline 1 & 0 & 0 \\
2 & 2 & 113455 \\
3 & 4 & 197389 \\
4 & 6 & 286789 \\
5 & 8 & 370610 \\
6 & 10 & 449783 \\
7 & 12 & 539245 \\
$\mathrm{R}^{2}$ & 0.997 & \\
Slope & 43993 & \\
Intercept & 15652 & \\
\hline
\end{tabular}

*Average of three determinants.

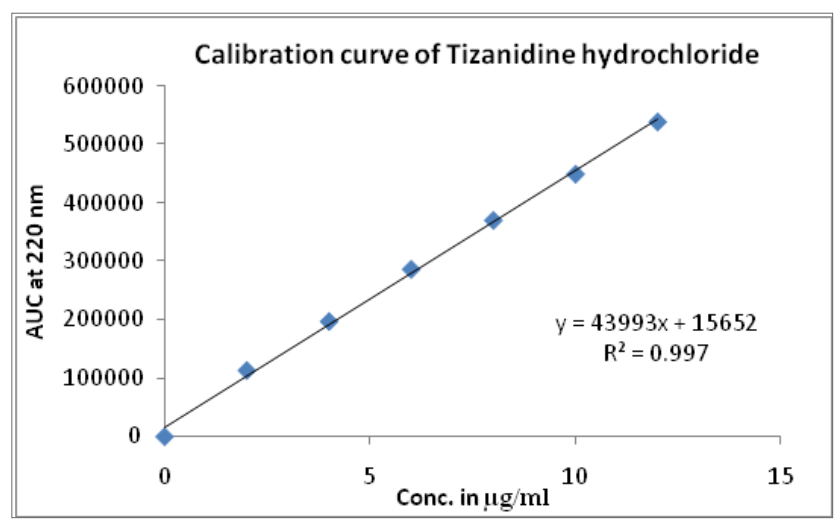

Figure 4 Calibration curve of TIZH by HPLC.

Table 3 Linear regression data of DICS and TIZH

\begin{tabular}{lllll}
\hline Drug & $\begin{array}{l}\text { Linearity range* } \\
(\mu \mathrm{\mu g} / \mathrm{mL})\end{array}$ & Slope* & y-intercept** & $\begin{array}{l}\text { Regression } \\
\text { coefficient* } \\
\left.\mathbf{( R}^{2}\right)\end{array}$ \\
\hline DICS & $6-16$ & 27403 & $6207 \pm 10.28$ & 0.998 \\
TIZH & $2-12$ & 43993 & $15652 \pm 8.73$ & 0.997 \\
\hline
\end{tabular}

*Average of three determinants.

\section{Precision}

The mean intra-day and inter-day precision \% RSD was found to be 0.01348 and 0.01317 for DICS respectively and 0.05097 and 0.04584 for TIZH respectively which were found to be less than $2 \%$. The results of the precision are given in Table 4.

Table 4 Precision Data of DICS and TIZH

\begin{tabular}{llll}
\hline Name of drug & Precision & Area* & \%RSD \\
\hline DICS & Intra-day & $28585 \mathrm{I}$ & 0.01348 \\
$(\mathrm{IO} \mu \mathrm{g} / \mathrm{ml})$ & Inter-Day & 285856 & 0.01317 \\
$\mathrm{TIZH}$ & Intra-day & 45575 & 0.05097 \\
$(0.68 \mu \mathrm{g} / \mathrm{ml})$ & Inter-Day & 45523 & 0.04584 \\
\hline
\end{tabular}

*Average of three determinants.

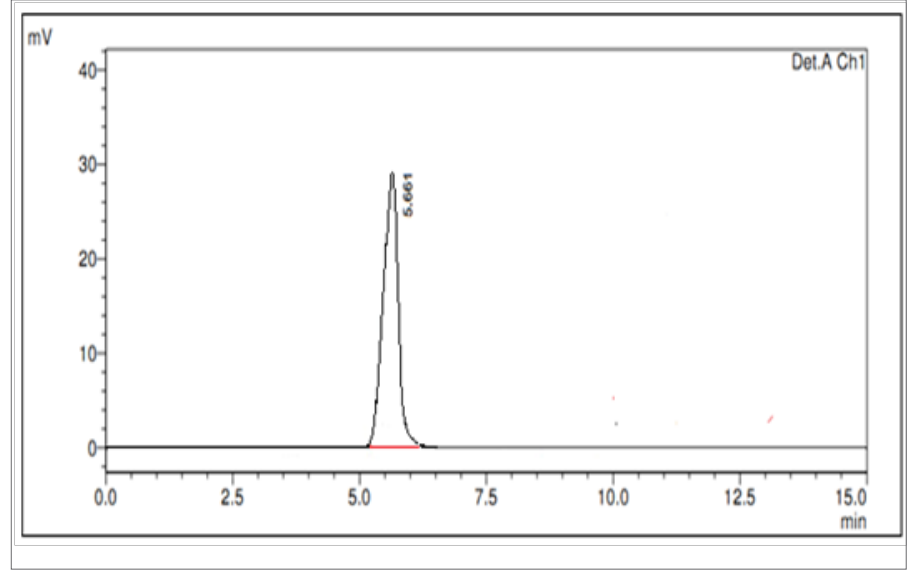

Figure 3 Chromatogram of pure $\mathrm{TIZH}$.

\section{Robustness}

The results presented in Table 5 indicate that the selected factors (retention time $t_{R}$, tailing factor $\mathrm{T}$, area and $\%$ content) were unaffected by small variations in flow rate of mobile phase.

Table 5 Robustness data of DICS and TIZH

\begin{tabular}{lll}
\hline Drug & Flow rate*(ml/min) & Area* \\
\hline DICS $(10 \mu \mathrm{g} / \mathrm{ml})$ & 0.9 & 285990 \\
& $\mathrm{I}$ & 285990 \\
& I.I & 285990 \\
$\operatorname{TIZH}(2 \mu \mathrm{g} / \mathrm{ml})$ & $\mathrm{I}$ & $\mathrm{I} \mid 3455$ \\
& $\mathrm{I} . \mathrm{I}$ & $\mathrm{I} \mid 3455$ \\
\hline
\end{tabular}

*Average of three determinants.

\section{Limit of detection and limit of quantization}

The results of Limit of Detection and Limit of Quantitation are presented in Table 6

Table 6 Limit of detection and limit of quantitation of DICS and TIZH

\begin{tabular}{lll}
\hline Name of drug & \multicolumn{2}{l}{ Parameters } \\
\hline & LOD* & LOQ* \\
DICS & $0.20 \mu \mathrm{g} / \mathrm{mL}$ & $1.10 \mu \mathrm{g} / \mathrm{ml}$ \\
TIZH & $0.10 \mathrm{ng} / \mathrm{mL}$ & $2.20 \mathrm{ng} / \mathrm{mL}$ \\
\hline
\end{tabular}

*Average of three determinants.

\section{$\%$ recovery study}

The recovery studies were carried out by spiking the test solution at 80,100 and $120 \%$ of the test concentration as per ICH guidelines. The results of the recovery studies are shown in Table 7. 
Table 7 Result of \% recovery study

\begin{tabular}{llll}
\hline Name of drug & $\begin{array}{l}\text { Excess drug } \\
\text { added }\end{array}$ & $\begin{array}{l}\text { Theoretical } \\
\text { drug } \\
\text { content* }\end{array}$ & \% Recovery* \\
\hline \multirow{2}{*}{ DICS } & $80 \%$ & $0.8 \mu \mathrm{g} / \mathrm{ml}$ & 98.55 \\
& $100 \%$ & $10 \mu \mathrm{g} / \mathrm{ml}$ & 100 \\
& $120 \%$ & $1.2 \mu \mathrm{g} / \mathrm{ml}$ & 98.92 \\
TIZH & $80 \%$ & $0.48 \mu \mathrm{g} / \mathrm{ml}$ & 100 \\
& $100 \%$ & $0.6 \mu \mathrm{g} / \mathrm{ml}$ & 98.6 \\
& $120 \%$ & $0.72 \mu \mathrm{g} / \mathrm{ml}$ & 99.7 \\
\hline
\end{tabular}

\section{Acknowledgements}

None.

\section{Conflict of interest}

The author declares that there is no conflict of interest.

\section{References}

1. Chien YW. Novel drug delivery system. $2^{\text {nd }}$ ed. New York: Marcel dekker Inc; 1991:139-140.

2. Chien YW. Novel drug delivery system. $2^{\text {nd }}$ ed. New York: Marcel dekker Inc; 1992:1-2.

3. Bankers GS, Rhodes CT. Modern pharmaceutics. $3^{\text {rd }}$ ed. New York: Marcel dekker Inc; 1993: 575.

4. Bankers GS, Rhodes CT. Modern pharmaceutics. $3^{\text {rd }}$ ed. New York: Marcel dekker Inc; 1995:6.
5. Bankers GS, Rhodes CT. Modern pharmaceutics. $3^{\text {rd }}$ ed. New York: Marcel dekker Inc; 1995: 577-578.

6. Bankers GS, Rhodes CT. Modern pharmaceutics. $3^{\text {rd }}$ ed. New York: Marcel dekker Inc; 1995: 579-580.

7. Lachman L, Liberman HA, Kanig JL. The theory and practice of industrial pharmacy. 3rd ed. India: Varghese publishing house; 1987:430.

8. Brahmankar DM, Jaiswal SB. Biopharmaceutics and pharmacokinetics-a treatise. 1st ed. India: Vallabh prakashan; 1995:347-371.

9. Lachman L, Liberman HA, Kanig JL. The theory and practice of industrial pharmacy. 3rd ed. India: Varghese publishing house; 1987:453.

10. Lachman L, Liberman HA, Kanig JL. The theory and practice of industrial pharmacy. 3rd ed. India: Varghese publishing house; 1987:443-453.

11. Jantzen GM, Robinson JR. Sustained and controlled release drug delivery system, modern pharmaceutics. New York: Marcel Dekker; 1987:71-121.

12. Karande A, Dhoke S, Yeole P. Formulation and evaluation of bilayer tablet with antihypertensive drugs having different release pattern. Indian Drugs. 2006;43(1):44-50.

13. Wang XCF, Yonezawa Y, Sunada H. Preparation and evaluation of combination tablet containing incompatible active ingredients. Chem Pharm Bull. 2003;51:7772.

14. Dressman B, Amidon GL. Reppas C. Dissolution testing as a prognostic tool for oral drug absorption: immediate release dosage forms. Pharm Res. 1998;15(1):11-22.

15. Subhramanian G, Musmade P, Agarwal S, et al. Simultaneous RP-HPLC estimation of tizanidine, diclofenac, paracetamol in tablets. Indian $J$ pharm Sci. 2004;694-696. 